\title{
Permselectivity of the Glomerular Capillary Wall
}

\author{
FACILITATED FILTRATION OF CIRCULATING POLYCATIONS
}

\author{
Michael P. Bohrer, Christine Baylis, H. David Humes, Richard J. Glassock, \\ Channing R. Robertson, and BARRY M. BRENNER, Laboratory of Kidney \\ and Electrolyte Physiology and Departments of Medicine, Peter Bent Brigham \\ Hospital and Harvard Medical School, Boston, Massachusetts 02115, \\ Department of Chemical Engineering, Stanford University, Stanford, \\ California 94305, and the Departments of Medicine, Harbor General Hospital, \\ Torrance, California 90509, and the University of California, \\ Los Angeles, California 90024
}

A B S T RACT To examine the electrostatic effects of fixed negative charges on the glomerular capillary wall, polydisperse $\left[{ }^{3} \mathrm{H}\right]$ DEAE dextran, a polycationic form of dextran, was infused into 10 Munich-Wistar rats. Fractional clearances of DEAE ranging in radius from 18 to $44 \AA$ were determined in these rats, together with direct measurements of the forces and flows governing the glomerular filtration rate of water. These results were compared with data previously obtained in MunichWistar rats receiving tritiated neutral dextran (D) and polyanionic dextran sulfate (DS). Measured values for the determinants of the glomerular filtration rate of water in rats given DEAE were found to be essentially identical to those in rats given either D or DS. In addition, DEAE was shown to be neither secreted nor reabsorbed. Fractional clearances of polycationic DEAE were increased relative to both D and DS, the increase relative to $D$ being significant for effective molecular radii ranging from 24 to $44 \AA$.

Fractional DEAE clearances were also measured in a separate group of six Munich-Wistar rats in the early autologous phase of nephrotoxic serum nephritis (NSN). Fractional DEAE clearances in NSN rats were reduced significantly, relative to values measured in normal rats, for effective DEAE radii ranging from 18 to

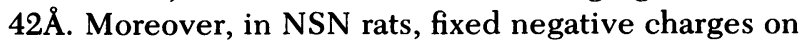
the glomerular capillary wall were greatly reduced,

Dr. Baylis is a Post-Doctoral Research Fellow of the National Kidney Foundation. Mr. Bohrer is a predoctoral student in Chemical Engineering at Stanford University.

Requests for reprints should be addressed to Mr. Bohrer at the Laboratory of Kidney and Electrolyte Physiology, Peter Bent Brigham Hospital, 721 Huntington Ave., Boston, Mass. 02115.

Received for publication 25 May 1977 and in revised form 15 August 1977. relative to non-NSN rats, as evidenced by a reduction in intensity of colloidal iron staining. Thus, in NSN rats, DEAE clearances were essentially indistinguishable from values obtained with both neutral $\mathrm{D}$ and polyanionic DS.

\section{INTRODUCTION}

In mammals the transglomerular passage of macromolecules is known to be influenced by molecular size as well as by the hemodynamic forces operating across the glomerular capillary wall (1-12). Recently, studies by the authors (13) and others (14-16) have provided clear evidence for a third determinant of macromolecular filtration, that resulting from the operation of the glomerular capillary wall as an electrostatic barrier. This barrier, determined by the presence normally of a variety of densely anionic glycosialoproteins in the various component layers of the glomerular capillary wall (fixed negative charges), has been shown to impede the transglomerular passage of circulating polyanions such as serum albumin, dextran sulfate, and succinylated forms of horseradish peroxidase and ferritin (13-16). Moreover, reduction in these fixed negative charges, induced either by immunological and (or) biochemical alterations of the glomerulus (17-23), is associated with a marked lessening of the effectiveness of this electrostatic barrier to the filtration of circulating polyanions (23-28).

Whereas the effect of these fixed negative charges on the glomerular capillary wall normally serves to impede the transmural passage of polyanions, such an anionic electrostatic barrier might be expected to enhance the filtration of circulating polycations. To test this possibility, the present study was undertaken in Munich-Wistar rats to determine renal clearances of 
polycationic $\left[{ }^{3} \mathrm{H}\right] \mathrm{DEAE}$ dextrans, relative to that of inulin, and to compare these fractional DEAE clearances to values obtained previously in this same strain of rats using both neutral dextran (D) and highly anionic dextran sulfate (DS) (12). In addition, DEAE fractional clearances were measured in a separate group of $\mathrm{Mu}$ nich-Wistar rats in which proteinuria and reduction of fixed negative charges on the glomerular capillary wall were induced by the injection of anti-glomerular basement membrane antibodies (nephrotoxic serum nephritis, NSN) $(23,29)$.

\section{GLOSSARY OF ABBREVIATIONS AND SYMBOLS}

\begin{tabular}{|c|c|}
\hline$\overline{\mathrm{AP}}$ & Arterial blood pressure. \\
\hline $\mathrm{C}_{\mathrm{A}}$ & Systemic plasma protein concentration. \\
\hline $\mathrm{C}_{\text {DEAE }} / \mathrm{C}_{\text {INULIN }}$ & $\begin{array}{l}\text { Fractional clearance of DEAE obtained for the } \\
\text { kidney as a whole. }\end{array}$ \\
\hline $\mathrm{c}_{\text {DEAE }} / \mathrm{c}_{\text {INULIN }}$ & $\begin{array}{l}\text { Fractional clearance of DEAE obtained for a } \\
\text { single glomerulus. }\end{array}$ \\
\hline $\mathrm{C}_{\mathrm{E}}$ & $\begin{array}{l}\text { Efferent arteriolar plasma protein concentra- } \\
\text { tion. }\end{array}$ \\
\hline $\mathrm{D}$ & Neutral dextran. \\
\hline DEAE & DEAE dextran. \\
\hline DS & Dextran sulfate. \\
\hline GFR & Glomerular filtration rate. \\
\hline$K_{f}$ & Ultrafiltration coefficient. \\
\hline NSN & Nephrotoxic serum nephritis. \\
\hline $\mathrm{P}_{\mathrm{GC}}$ & $\begin{array}{l}\text { Mean hydraulic pressure in surface glomerular } \\
\text { capillaries. }\end{array}$ \\
\hline $\mathbf{P}_{\mathbf{T}}$ & $\begin{array}{l}\text { Hydraulic pressure in the early proximal } \\
\text { tubules. }\end{array}$ \\
\hline$\overline{\Delta \mathrm{P}}$ & $\begin{array}{l}\text { Mean net transcapillary hydraulic pressure dif- } \\
\text { ference. }\end{array}$ \\
\hline$\Pi_{\mathrm{A}}$ & Afferent oncotic pressure. \\
\hline$\Pi_{\mathbf{E}}$ & ncotic pressure. \\
\hline$Q_{A}$ & Initial glomerular capillary plasma flow rate. \\
\hline & \\
\hline & lomerular filtration rate of a single nephror \\
\hline
\end{tabular}

\section{METHODS}

Animal studies. Studies were performed in 12 normal hydropenic Munich-Wistar rats and in a separate group of six Munich-Wistar rats in which NSN was induced in a manner similar to that described recently $(23,24)$. NSN rats received $100 \mu \mathrm{g}$ of rabbit IgG anti-rat glomerular basement membrane antibody 2-3 days after a subcutaneous immunization with partially aggregated normal rabbit IgG incorporated in Freund's incomplete adjuvant. The clearance and micropuncture measurements were performed in the NSN rats an average of 18 days after the injection of anti-glomerular basement membrane antibody (range 15-24 days). Protein excretion, measured with the biuret method (30), in five NSN rats in the 1-6-day period before fractional clearance studies averaged $43.8 \mathrm{mg} / 24 \mathrm{~h}$ with a range of $22.1-57.1 \mathrm{mg} / 24 \mathrm{~h}$. Protein excretion rates for normal Munich-Wistar rats of comparable size and age averaged $2.3 \pm 0.09 \mathrm{mg} / 24 \mathrm{~h} \mathrm{SEM}$ in six rats.

Exactly timed samples of fluid were obtained from superficial proximal tubules for measurement of tubule fluid flow rate and inulin concentration, and for calculation of the glomerular filtration rate (GFR) of a single nephron (SNGFR). Systemic and efferent arteriolar plasma protein concentrations
$\left(C_{A}\right.$ and $\left.C_{E}\right)$ were also determined. These estimates of $C_{A}$ and $C_{E}$ permit calculation of afferent $\left(\Pi_{A}\right)$ and efferent $\left(\Pi_{E}\right)$ oncotic pressures, single nephron filtration fraction (SNFF), and initial glomerular capillary plasma flow rate $\left(Q_{A}\right)$, using equations reported previously $(31,32)$. Hydraulic pressures were measured in surface glomerular capillaries $\left(\overline{\mathrm{P}}_{\mathrm{GC}}\right)$ and early proximal tubules $\left(\mathbf{P}_{\mathrm{T}}\right)$ using the servonull micropipet transducer technique of Wiederhielm et al. (33). In addition, arterial blood pressure $(\overline{\mathrm{AP}})$ was monitored, and whole kidney GFR measured, throughout the period of micropuncture. After completion of the above micropuncture measurements, $\left[{ }^{3} \mathrm{H}\right]$ DEAE dextran (Pharmacia Fine Chemicals, Div. of Pharmacia Inc., Piscataway, N.J.) of wide molecular size distribution (DEAE dextran concentration $\simeq 300 \mathrm{mg} / 100 \mathrm{ml}$, activity $\simeq 0.025 \mathrm{mCi} / \mathrm{ml}$ ) was infused intravenously at the rate of $1.2 \mathrm{ml} / \mathrm{h}$, and samples of urine and blood were collected for determination of DEAE and inulin concentrations. These experimental procedures, as well as the methods of preparation and tritiation of DEAE, are similar to those described previously for D and DS $(1,13)$, with the exception that, in this study, samples of femoral arterial plasma and urine were mixed with $1 \mathrm{ml}$ of an $0.15 \mathrm{~N}$ ammonium acetate solution containing $2 \mathrm{mg}$ of untritiated DEAE, before column chromatography. Gel chromatographic separation of DEAE in plasma and urine, for determination of molecular size, was carried out on Sephadex G-100 (Pharmacia Fine Chemicals) using an $0.15 \mathrm{~N}$ solution of ammonium acetate containing $2 \mathrm{mg} / \mathrm{ml}$ nonisotopic DEAE as buffer.

Studies were performed in four normal hydropenic rats and three NSN rats to evaluate whether DEAE undergoes net secretion or reabsorption by the renal tubules. This was accomplished by comparison of fractional clearances of DEAE $\left(\mathrm{C}_{\mathrm{DEAE}} / \mathrm{C}_{\text {INULIN }}\right)$ obtained for the kidney as a whole, with fractional DEAE clearances for single glomeruli ( $\left.c_{\text {DEAE }} / c_{\text {INULIN }}\right)$. In these studies DEAE fractions of narrow molecular size distribution with peaks at 19 and $27 \AA$ were employed (DEAE concentration $\simeq 300 \mathrm{mg} / \mathrm{ml}$, activity $\simeq 0.050 \mathrm{mCi} / \mathrm{ml}$ ), as described previously for D and DS $(1,13)$.

At the conclusion of the DEAE infusion and fractional clearance studies, rats with NSN were sacrificed, and coronal sections of the right and left kidneys were fixed in $10 \%$ neutral buffered formalin and processed for hemotoxylin and eosin and colloidal iron stains as described previously $(23,29)$. The degree of glomerular injury and the intensity of colloidal iron staining of the glomerular capillary wall was assessed in a semiquantitative fashion using an arbitrary scale $(0-4+)$.

\section{RESULTS}

Table I and Fig. 1A summarize values in 10 normal rats for $\mathrm{C}_{\mathrm{DEAE}} / \mathrm{C}_{\mathrm{INULIN}}$ obtained for DEAE molecules ranging from 18 to $44 \AA$. For comparison, mean fractional clearance values obtained with neutral $D$ and polyanionic DS are also shown, based on data reported previously (12). The findings indicate that the filtration of polycationic DEAE is enhanced appreciably, relative to that of neutral $D$, the mean difference between DEAE and neutral $D$ being significant $(P<0.05)$ for radii $>22 \AA$. As is also shown in Table $I$ and Fig. $1 \mathrm{~A}$, fractional clearance values of polycationic DEAE were profoundly enhanced, relative to those of anionic DS, for all molecular radii studied.

Values for $\mathrm{C}_{\mathrm{DEAE}} / \mathrm{C}_{\mathrm{INULIN}}$ obtained in six NSN rats are summarized in Table II and Fig. 1B. In NSN rats, mean fractional DEAE clearances were substantially lower, 
TABLE I

Summary of Fractional Clearance Values for DEAE Dextran, Neutral Dextran, and Dextran Sulfate of Varying Molecular Size in Normal Rats

\begin{tabular}{|c|c|c|c|c|c|c|c|c|c|c|c|c|c|c|}
\hline \multirow{2}{*}{$\begin{array}{c}\text { Tracer } \\
\text { employed } \AA \ldots\end{array}$} & \multicolumn{14}{|c|}{ Fractional clearance } \\
\hline & 18 & 20 & 22 & 24 & 26 & 28 & 30 & 32 & 34 & 36 & 38 & 40 & 42 & 44 \\
\hline $\begin{array}{l}\text { DEAE dextran } \\
(n=10 \text { rats })\end{array}$ & $\begin{array}{r}1.00 \\
\pm 0.02\end{array}$ & $\begin{array}{r}0.99 \\
\pm 0.03\end{array}$ & $\begin{array}{r}0.97 \\
\pm 0.04\end{array}$ & $\begin{array}{r}0.93 \\
\pm 0.05\end{array}$ & $\begin{array}{r}0.87 \\
\pm 0.05\end{array}$ & $\begin{array}{r}0.80 \\
\pm 0.06\end{array}$ & $\begin{array}{r}0.74 \\
\pm 0.07\end{array}$ & $\begin{array}{r}0.66 \\
\pm 0.07\end{array}$ & $\begin{array}{r}0.56 \\
\pm 0.07\end{array}$ & $\begin{array}{r}0.44 \\
\pm 0.05\end{array}$ & $\begin{array}{r}0.32 \\
\pm 0.04\end{array}$ & $\begin{array}{r}0.20 \\
\pm 0.03\end{array}$ & $\begin{array}{r}0.11 \\
\pm 0.02\end{array}$ & $\begin{array}{r}0.04 \\
\pm 0.01\end{array}$ \\
\hline$P$ value* & NS & NS & NS & $<0.010$ & $<0.005$ & $<0.001$ & $<0.001$ & $<0.001$ & $<0.001$ & $<0.001$ & $<0.001$ & $<0.001$ & $<0.001$ & $<0.001$ \\
\hline $\begin{array}{l}\text { Neutral dextran } \\
(n=7 \text { rats })\end{array}$ & $\begin{array}{r}1.00 \\
\pm 0.02\end{array}$ & $\begin{array}{r}0.97 \\
\pm 0.03\end{array}$ & $\begin{array}{r}0.87 \\
\pm 0.04\end{array}$ & $\begin{array}{r}0.73 \\
\pm 0.04\end{array}$ & $\begin{array}{r}0.60 \\
\pm 0.03\end{array}$ & $\begin{array}{r}0.45 \\
\pm 0.03\end{array}$ & $\begin{array}{r}0.32 \\
\pm 0.02\end{array}$ & $\begin{array}{r}0.22 \\
\pm 0.02\end{array}$ & $\begin{array}{r}0.15 \\
\pm 0.01\end{array}$ & $\begin{array}{r}0.090 \\
\pm 0.007\end{array}$ & $\begin{array}{r}0.045 \\
\pm 0.007\end{array}$ & $\begin{array}{r}0.022 \\
\pm 0.005\end{array}$ & $\begin{array}{r}0.008 \\
\pm 0.001\end{array}$ & $\begin{array}{r}0.002 \\
\pm 0.001\end{array}$ \\
\hline $\begin{array}{c}\text { Dextran sulfate } \\
\text { ( } n=7 \text { rats) }\end{array}$ & $\begin{array}{r}0.56 \\
\pm 0.05\end{array}$ & $\begin{array}{r}0.35 \\
\pm 0.03\end{array}$ & $\begin{array}{r}0.19 \\
\pm 0.02\end{array}$ & $\begin{array}{r}0.11 \\
\pm 0.02\end{array}$ & $\begin{array}{r}0.06 \\
\pm 0.01\end{array}$ & $\begin{array}{r}0.032 \\
\pm 0.007\end{array}$ & $\begin{array}{r}0.020 \\
\pm 0.004\end{array}$ & $\begin{array}{r}0.013 \\
\pm 0.003\end{array}$ & $\begin{array}{r}0.007 \\
\pm 0.001\end{array}$ & $\begin{array}{c}0.003 \\
\pm 0.0003\end{array}$ & $\begin{array}{c}0.0009 \\
\pm 0.00007\end{array}$ & $\begin{array}{c}0.0004 \\
\pm 0.00008\end{array}$ & $\begin{array}{c}0.0002 \\
\pm 0.00008\end{array}$ & $\begin{array}{c}0.0001 \\
\pm 0.00003\end{array}$ \\
\hline
\end{tabular}

Values expressed as means \pm 1 SEM.

* $P$ values calculated from $t$ test for unpaired means for DEAE dextran vs. neutral dextran.

at any given molecular size, than those found in normal rats.

Studies with DEAE molecules of narrow size distribution performed in four normal and three NSN rats demonstrated that $\mathrm{c}_{\mathrm{DEAE}} / \mathrm{c}_{\mathrm{INULIN}}$ ratios were essentially the same as simultaneously measured fractional DEAE clearance ratios obtained for the kidney as a whole $\left(\mathrm{C}_{\mathrm{DEAE}} / \mathrm{C}_{\mathrm{INULIN}}\right)$. Values for the ratio $\left(\mathrm{c}_{\mathrm{DEAE}} / \mathrm{c}_{\mathrm{INULIN}}\right) /\left(\mathrm{C}_{\mathrm{DEAE}} /\right.$ $\mathrm{C}_{\mathrm{INULIN}}$ ) for nine such comparisons in normal rats and seven comparisons in NSN rats averaged $1.02 \pm 0.03$ and $1.00 \pm 0.02$, respectively. These values did not differ significantly from unity $(P>0.5)$. These findings demonstrate that, in both normal and NSN rats, DEAE molecules are neither secreted nor reabsorbed by the renal tubules. Similar conclusions have previously been reached for D and DS $(1,13)$.
Table III summarizes mean values for several indices of single nephron and whole kidney function in five of the normal hydropenic rats given DEAE. Values for whole kidney GFR, SNGFR, and $\mathrm{Q}_{\mathrm{A}}$ averaged 0.92 $\pm 0.09 \mathrm{ml} / \mathrm{min}, 33.3 \pm 1.6$ and $86.8 \pm 9.7 \mathrm{nl} / \mathrm{min}$, respectively, essentially similar to values reported for normal hydropenic rats given D and DS (12). Values for $\overline{\mathrm{AP}}$ and $\overline{\mathrm{P}}_{\mathrm{GC}}$ averaged $120 \pm 3 \mathrm{~mm} \mathrm{Hg}$ and $49 \pm 0.4 \mathrm{~mm} \mathrm{Hg}$ in rats receiving DEAE, both parameters being slightly greater than in the D and DS groups, whereas values for $P_{T}$ were similar in all three groups. There was little difference among the values for $C_{A}$ (and thus $\Pi_{A}$ ) in the three groups of normal hydropenic rats, although $C_{E}$ (and thus $\Pi_{E}$ ) in DEAE rats were slightly, but significantly, greater than mean values for $C_{E}$ and $\Pi_{E}$ in $D$ and DS rats, due to the slightly greater values for the mean

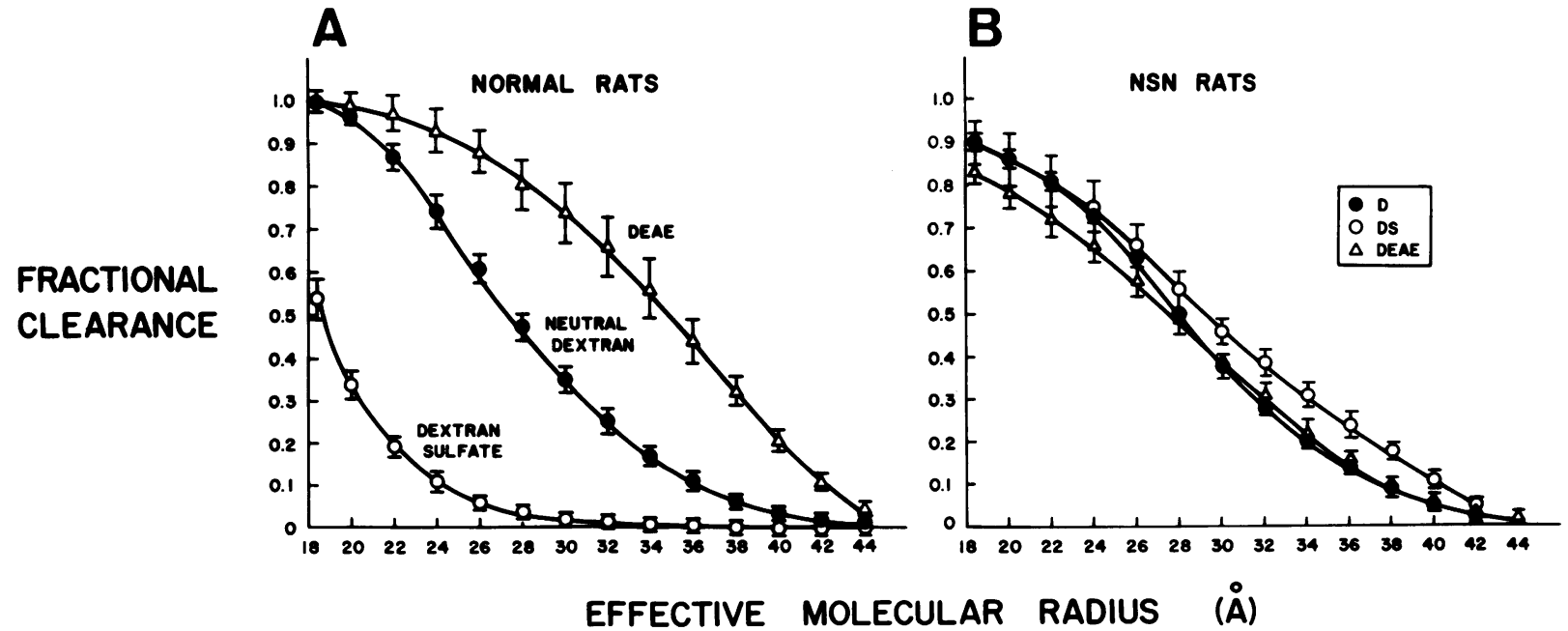

FIGURE 1 Fractional clearances of DEAE dextran, neutral dextran, and dextran sulfate, plotted as a function of effective molecular radius in normal rats (A) and in NSN rats (B). Values are expressed as means \pm 1 SEM. Results for neutral dextran and dextran sulfate have been reported in detail previously $(12,23,24)$. 
TABLE II

Summary of Fractional Clearance Values for DEAE Dextran, Neutral Dextran, and Dextran Sulfate of Varying Molecular Size in NSN Rats

\begin{tabular}{|c|c|c|c|c|c|c|c|c|c|c|c|c|c|c|}
\hline \multirow{2}{*}{$\begin{array}{c}\text { Tracer } \\
\text { employed } \AA . . .\end{array}$} & \multicolumn{14}{|c|}{ Fractional clearance } \\
\hline & 18 & 20 & 22 & 24 & 26 & 28 & 30 & 32 & 34 & 36 & 38 & 40 & 42 & 44 \\
\hline \multirow{2}{*}{$\begin{array}{c}\text { DEAE dextran } \\
\quad(n=6 \text { rats })\end{array}$} & 0.83 & 0.78 & 0.72 & 0.66 & 0.58 & 0.49 & 0.39 & 0.31 & 0.22 & 0.15 & 0.09 & 0.05 & 0.03 & 0.02 \\
\hline & \pm 0.03 & \pm 0.04 & \pm 0.04 & \pm 0.04 & \pm 0.04 & \pm 0.04 & \pm 0.04 & \pm 0.03 & \pm 0.03 & \pm 0.02 & \pm 0.02 & \pm 0.01 & \pm 0.01 & \pm 0.01 \\
\hline \multirow{2}{*}{$\begin{array}{l}\text { Neutral dextran } \\
\qquad(n=8 \text { rats })\end{array}$} & 0.90 & 0.86 & 0.81 & 0.73 & 0.63 & 0.50 & 0.38 & 0.28 & 0.20 & 0.14 & 0.09 & 0.05 & 0.025 & - \\
\hline & \pm 0.02 & \pm 0.02 & \pm 0.02 & \pm 0.02 & \pm 0.02 & \pm 0.02 & \pm 0.02 & \pm 0.01 & \pm 0.01 & \pm 0.01 & \pm 0.005 & \pm 0.005 & \pm 0.005 & - \\
\hline \multirow{2}{*}{$\begin{array}{l}\text { Dextran sulfate } \\
\quad(n=9 \text { rats })\end{array}$} & 0.90 & 0.86 & 0.81 & 0.75 & 0.66 & 0.56 & 0.46 & 0.39 & 0.31 & 0.24 & 0.18 & 0.11 & 0.05 & - \\
\hline & \pm 0.05 & \pm 0.06 & \pm 0.06 & \pm 0.06 & \pm 0.05 & \pm 0.04 & \pm 0.03 & \pm 0.03 & \pm 0.03 & \pm 0.03 & \pm 0.02 & \pm 0.02 & \pm 0.01 & - \\
\hline
\end{tabular}

Values expressed as means \pm 1 SEM.

net transcapillary hydraulic pressure difference, $\overline{\Delta \mathrm{P}}$, $\left(\overline{\mathbf{P}}_{G C}-\mathrm{P}_{T}\right)$, in the DEAE group. SNFF was slightly greater in normal hydropenic rats given DEAE (averaging $0.42 \pm 0.02)$ than in rats given $\mathrm{D}(0.38 \pm 0.01)$ or $\mathrm{DS}$ $(0.40 \pm 0.01)$. Despite these relatively small differences in mean values among the three groups of rats, all values are within the range previously reported for the normal hydropenic Munich-Wistar rat (34). Furthermore, in all three groups of rats studied, the normal hydropenic condition of filtration pressure equilibrium obtained, as evidenced by mean ratios for $\Pi_{\mathrm{E}} / \Delta \overline{\mathrm{P}} \simeq 1.00$, as shown in Table III and reported previously (12).

Table III also summarizes mean values for these same indices of single nephron and whole kidney function measured in four NSN rats given DEAE. Mean values for GFR, SNGFR, and $Q_{A}$ averaged $0.64 \pm 0.10 \mathrm{ml} /$ $\mathrm{min}, 22.7 \pm 3.5 \mathrm{nl} / \mathrm{min}$, and $58.7 \pm 11.4 \mathrm{nl} / \mathrm{min}$, respectively. These values are moderately lower than the mean values reported previously for NSN rats given D and DS $(23,24)$. Of note, these lower values of GFR, SNGFR, and $Q_{A}$ were obtained in rats which were found to have somewhat more severe glomerular injury than was noted in NSN rats reported by us previously $(23,24)$, as evidenced both morphologically and by the slightly lower value of $K_{f}$. Values for $\overline{\mathrm{P}}_{\mathrm{GC}}$ were slightly, but significantly higher in NSN rats given DEAE than those given
D or DS; all values for $\overline{\mathbf{P}}_{\mathrm{GC}}$ in the various NSN groups were significantly increased relative to values found in normal rats. On average, the value for SNFF was slightly higher $(0.40 \pm 0.03)$ in the NSN rats given DEAE than the corresponding value in NSN rats given $\mathrm{D}(0.31 \pm 0.02)$ or DS $(0.34 \pm 0.02)$. Values for $\overline{\mathrm{AP}}, \mathrm{P}_{\mathrm{T}}$, $\mathrm{C}_{\mathrm{A}}, \mathrm{C}_{\mathrm{E}}, \Pi_{\mathrm{A}}$, and $\Pi_{\mathrm{E}}$ were essentially the same as values both for NSN rats given D and DS, as well as for normal rats given DEAE. As was found previously for NSN rats, the ratio $\Pi_{E} / \overline{\Delta P}$, which averaged $0.72 \pm 0.07$ in the rats given DEAE, deviated significantly from unity $(\mathrm{P}<0.05)$, indicating that filtration pressure equilibrium was not achieved. When filtration pressure equilibrium is not achieved, a unique value for the glomerular capillary ultrafiltration coefficient $\left(K_{f}\right)$ can be calculated (35). In the present study, $K_{f}$ averaged $0.020 \pm 0.008 \mathrm{nl} /(\mathrm{s} \cdot \mathrm{mm} \mathrm{Hg})$, a value similar to that reported previously for NSN rats $(23,24)$.

All NSN rats examined in the present study had evidence of significant glomerular injury, ranging from 2 to $4+$ on an arbitrary, semiquantitative scale. Glomerular lesions consisted of diffuse endocapillary proliferation with segmental occlusion of capillary lumena and occasional segmental epithelial cell crescents. Tubulointerstitial lesions were scanty and consisted primarily of widely scattered foci of tubular atrophy and dilation.

TABLE III

Summary of Measured Determinants of Glomerular Ultrafiltration in Normal and NSN Rats Given DEAE Dextran

\begin{tabular}{|c|c|c|c|c|c|c|c|c|c|c|c|c|c|}
\hline & Body wt & $\overline{\mathbf{A P}}$ & $\overline{\mathbf{P}}_{\mathrm{GC}}$ & $\mathbf{P}_{\mathrm{T}}$ & $\mathrm{C}_{\mathrm{A}}$ & $\mathrm{C}_{\mathrm{E}}$ & $\Pi_{\mathrm{A}}$ & $\Pi_{\mathrm{E}}$ & $\Pi_{\mathbf{E}} / \overline{\Delta \mathbf{P}}$ & SNGFR & $Q_{A}$ & SNFF & GFR \\
\hline & $g$ & & $m m \mathrm{Hg}$ & & & & & & & & & & $\begin{array}{c}m l l \\
m i n\end{array}$ \\
\hline $\begin{array}{l}\text { Normal rats } \\
\quad(n=5)\end{array}$ & $\begin{array}{l}275 \\
\pm 13\end{array}$ & $\begin{array}{r}120 \\
\pm 3\end{array}$ & $\begin{array}{l}49 \\
\pm 0.4\end{array}$ & $\begin{array}{c}12 \\
\pm 0.6\end{array}$ & $\begin{array}{r}5.1 \\
\pm 0.2\end{array}$ & $\begin{array}{r}8.9^{*} \\
\pm 0.1\end{array}$ & $\begin{array}{r}16.0 \\
\pm 0.8\end{array}$ & $\begin{array}{l}37.9 * \\
\pm 0.7\end{array}$ & $\begin{array}{l}1.03^{*} \\
\pm 0.01\end{array}$ & $\begin{array}{r}33.3 \\
\pm 1.6\end{array}$ & $\begin{array}{l}86.8^{*} \\
\pm 9.7\end{array}$ & $\begin{aligned} & 0.42^{*} \\
\pm & 0.02\end{aligned}$ & $\begin{array}{r}0.92 \\
\pm 0.09\end{array}$ \\
\hline $\begin{array}{l}\text { NSN rats } \\
(n=4)\end{array}$ & $\begin{array}{r}224 \\
\pm 3\end{array}$ & $\begin{array}{r}121 \\
\pm 5\end{array}$ & $\begin{array}{l}55 \\
\pm 0.6\end{array}$ & $\begin{array}{c}12 \\
\pm 2.5\end{array}$ & $\begin{array}{r}4.7 \\
\pm 0.2\end{array}$ & $\begin{array}{r}7.8 \\
\pm 0.2\end{array}$ & $\begin{array}{r}14.4 \\
\pm 1.0\end{array}$ & $\begin{array}{r}30.6 \\
\pm 1.3\end{array}$ & $\begin{array}{r}0.72 \\
\pm 0.07\end{array}$ & $\begin{array}{r}22.7 \\
\pm 3.5\end{array}$ & $\begin{array}{r}58.7 \\
\pm 11.4\end{array}$ & $\begin{array}{r}0.40 \\
\pm 0.03\end{array}$ & $\begin{array}{r}0.64 \\
\pm 0.10\end{array}$ \\
\hline$P$ valuest & $<0.025$ & NS & $<0.001$ & NS & NS & $<0.005$ & NS & $<0.005$ & $<0.005$ & NS & NS & NS & NS \\
\hline
\end{tabular}

Values expressed as means \pm 1 SEM.

$* n=4$ rats.

t $P$ values calculated from $t$ test for unpaired means. 
No significant vascular lesions were observed. Glomerular lesions were qualitatively similar to those described previously in this model $(23,24)$ but quantitatively somewhat more severe, very likely reflecting the somewhat higher dose of anti-glomerular basement membrane antibody used in the present study. The colloidal iron staining was reduced but not eliminated in the glomeruli of the NSN rats when compared to normal control tissue, as noted previously as well (23, 24). In more severely affected glomeruli, loss of staining with colloidal iron was nearly complete but this was not uniform from glomerulus to glomerulus.

\section{DISCUSSION}

Recent studies have demonstrated that the transglomerular passage of circulating, charged macromolecules is influenced not only by molecular size and hemodynamic factors but also by the electrostatic characteristics of the glomerular capillary wall. Several in vivo studies have shown that fractional clearance values for uncharged solutes (i.e., dextrans) or solutes with isoelectric points brought to or near neutrality by chemical modification (ferritins and horseradish peroxidases) greatly exceed those measured for their negatively charged counterparts of equivalent molecular radius $(12,13,15,16)$. Similarly, whereas the fractional clearance of neutral dextran with an effective molecular radius of $36 \AA$ averaged $\sim 0.090$, the fractional clearance of albumin, an anionic plasma protein of equivalent effective radius, is at least two orders of magnitude lower, averaging $<0.001(36)$.

Studies by Chang et al. $(1,13)$ and Bohrer et al. (12), utilizing neutral and polyanionic DS demonstrated that inasmuch as D and DS are neither secreted nor reabsorbed by the renal tubules to any measurable extent, differences in transport across tubule epithelia cannot account for the measured differences in fractional clearances of these neutral and polyanionic dextrans. Furthermore, because the measured glomerular pressures and flows in normal rats given $\mathrm{D}$ and those given DS were virtually identical (12), the dissimilar clearance profiles for D and DS cannot be ascribed to hemodynamic influences. Thus, differences in the transport of D and DS, as well as between neutral and anionic forms of ferritin (15) and horseradish peroxidase (16), suggest that restriction to the transglomerular passage of circulating polyanions, including albumin, is the result of electrostatic repulsion by some fixed, negatively charged component(s) of the glomerular capillary wall.

In addition to retarding the transglomerular passage of circulating polyanions, the highly anionic glomerular capillary wall might be expected to enhance the filtration of circulating polycations. This hypothesis is confirmed by the experimental observations made in the present study, where fractional clearances of the highly cationic dextran, DEAE, were enhanced, relative to neutral $D$, over a wide range of molecular radii studied. As shown in Fig. 1A and Table I, the order of fractional clearance values for different dextrans is: DEAE $>$ D $>$ DS.

That differences in macromolecular charge are largely responsible for the marked enhancement of DEAE clearances, relative to neutral $D$ and anionic DS, is strongly supported by the hemodynamic measurements given in Table III and reported previously (12). It is apparent that the hemodynamic forces which operate to control glomerular ultrafiltration were essentially similar among the three groups of normal hydropenic rats studied. Theoretical predictions indicate that the small differences that were observed among the three groups cannot account for the magnitude of the observed differences in fractional clearances of DEAE, $\mathrm{D}$, and DS (7).

Evidence for the existence of an electrostatic interaction between the glomerular capillary wall and circulating charged macromolecules has also been provided by Rennke et al. (14). These researchers compared the penetrance of neutral, anionic, and cationic electron-dense ferritins across glomerular capillary walls of the mouse, utilizing ultrastructural techniques, and showed considerably greater penetration of the cationic form of the tracer into the deepest layer of the glomerular basement membrane, the lamina rara externa, than was observed for neutral or anionic ferritins of equivalent size. More recently, Rennke et al. (15, 16) also employed these same ferritins as well as anionic, cationic, and neutral forms of horseradish peroxidase in in vivo studies in the rat and again noted enhanced transglomerular passage of the cationic forms of these test macromolecules, relative to both their neutral and anionic counterparts.

As to the nature of these negative fixed charges, highly anionic structural components of the normal glomerular capillary wall have been demonstrated morphologically, based on selective binding of a variety of cationic stains, including colloidal iron, alcian blue, ruthenium red, and lysozyme. Binding of cationic substances has been demonstrated for all layers of the glomerular wall. In this regard, it has been known for some time that the glomerular epithelial cell and its foot processes are covered with a thin layer of acidic glycoproteins (sialoproteins or glomerular polyanion) which are highly negatively charged. Similarly, the epithelial slit diaphragm (a thin membrane lying between channels formed by the interdigitating foot processes) is coated with sialoprotein, and the glomerular basement membrane, as well as the endothelial cell coat, have also been shown to contain sialoproteins. Whereas any or all of these highly anionic structural components could conceivably contribute to normal electrostatic barrier function, it has been suggested $(15,37)$ that the 
most proximal layers (endothelium and lamina rara interna) are likely to provide the primary barriers to circulating polyanions.

Yet another way of examining glomerular electrostatic barrier function is provided by the results of the experiments in the present study in which the presence of fixed negative charges in glomeruli was reduced by the induction of NSN. The impact of this reduced fixed charge content on fractional clearances of polyanionic DS is shown in Fig. 1., wherein comparison of A and B reveals that the transglomerular passage of polyanionic DS is not restricted to the same extent in NSN rats as in normal rats. This enhanced transglomerular passage of DS correlates well with the reduction in fixed negative charge on the glomerular capillary wall which has been shown to occur in NSN rats $(23,29)$.

Such a reduction in fixed wall charge might also be expected to reduce the transglomerular passage of polycationic DEAE dextran, since the normally favored influence of these wall charges on DEAE would be lessened. The present experiments confirm this hypothesis, since the loss of fixed charges as a result of the NSN lesion now results in a rather pronounced reduction in fractional DEAE clearances, relative to values in normal rats, for nearly all radii studied. As can be seen in Fig. IB, fractional clearances of polyanions such as DS, and polycations such as DEAE behave much like that of uncharged polymers, such as neutral D, in that fractional clearances for all three forms of dextran in NSN rats now assume quantitatively nearly indistinguishable values. In effect, then, with nephritis-induced loss of charge discrimination, the glomerular barrier becomes essentially only size-selective, and processes highly anionic and cationic molecules in much the same way as it processes neutral polymers. Since the resulting size-selective barrier is not very restrictive for molecules with radii equivalent to that of serum albumin, $\sim 36 \AA$, the presence of substantial amounts of albumin in the urine can now be seen to be a rather predictable, albeit highly undesirable, consequence of this form of glomerular injury.

In all likelihood, this reduction in fractional DEAE clearances in NSN rats is due not only to the reduction in fixed wall negative charges, but also to the reduction in $K_{f}$ observed in these rats. As reported previously (24), the fall in $K_{f}$ noted in NSN rats is probably due to a reduction in the surface area available for filtration. Using a theoretical model described previously (7), as well as measured values for $K_{f}, \overline{\Delta \mathrm{P}}, \mathrm{C}_{\mathrm{A}}$, and $\mathrm{Q}_{\mathrm{A}}$, and assuming no electrostatic driving forces, the portion of the decline in fractional DEAE clearances due to the fall in $K_{f}$ was estimated to average $\sim 1 / 3$ of the total decline for essentially all radii studied. The remainder, $\sim 2 / 3$ of the fall in fractional DEAE clearances, is therefore attributed to electrostatic factors.

\section{ACKNOWLEDGMENTS}

The authors wish to acknowledge the technical assistance of Alice J. Anderson, Bennett S. Kayser, Julia L. Troy, and Wayne T. Willis, and secretarial assistance of Mrs. Debra Anne Bohrer.

This study was supported by grants AM 19467, HE 14945, and AM 16565 of the National Institutes of Health.

\section{REFERENCES}

1. Chang, R. L. S., I. F. Ueki, J. L. Troy, W. M. Deen, C. R. Robertson, and B. M. Brenner. 1975. Permselectivity of the glomerular capillary wall to macromolecules. II. Experimental observations in the rat. Biophys. J. 15: 887906.

2. Farquhar, M. G. 1975. The primary glomerular filtration barrier-basement membrane or epithelial slits? Kidney Int. 8: 197-211.

3. Renkin, E. M., and J. P. Gilmore. 1973. Glomerular filtration. Handb. Physiol. (Sect. 8. Renal Physiol.): 185-248.

4. Hardwicke, J., J. S. Cameron, J. F. Harrison, B. Hulme, and J. F. Soothill, 1970. Proteinuria studied by clearances of individual macromolecules. In Proteins in Normal and Pathological Urine. Y. Manuel, J. P. Revillard, and H. Betuel, editors. University Park Press, Baltimore, Md. $111-152$.

5. Verniory, A., R. DuBois, R. Decoodt, J. P. Gassée, and P. P. Lambert. 1973. Measurement of the permeability of biological membranes. Application to the glomerular wall. J. Gen. Physiol. 62: 489-507.

6. Arturson, G., T. Groth, and G. Grotte. 1971. Human glomerular membrane porosity and filtration pressure: Dextran clearance data analyzed by theoretical models. Clin. Sci. (Oxf.) 40: 137-158.

7. Chang, R. L. S., C. R. Robertson, W. M. Deen, and B. M. Brenner. 1975. Permselectivity of the glomerular capillary wall to macromolecules. I. Theoretical considerations. Biophys. J. 15: 861-886.

8. DuBois, R., P. Decoodt, J. P. Gassée, A. Verniory, and P. P. Lambert. 1975. Determination of glomerular intracapillary and transcapillary pressure gradients from sieving data. I. A mathematical model. Pflügers Arch. Eur. J. Physiol. 356: 299-316.

9. Lambert, P. P., R. DuBois, P. Decoodt, J. P. Gassée, and A. Verniory. 1975. Determination of glomerular intracapillary and transcapillary pressure gradients from sieving data. II. A physiological study in the normal dog. Pflügers Arch. Eur. J. Physiol. 359: 1-22.

10. Gassée, J. P., R. DuBois, M. Staroukine, and P. P. Lambert. 1976. Determination of glomerular intracapillary and transcapillary pressure gradients from sieving data. 3 . The effects of angiotensin II. Pflügers Arch. Eur. J. Physiol. 367: 15-24.

11. Gassée, J. P. 1973. Effect of acetylcholine on glomerular sieving of macromolecules. Pflügers Arch. Eur. J. Physiol. 342: 239-254.

12. Bohrer, M. P., W. M. Deen, C. R. Robertson, and B. M. Brenner. 1977. Mechanism of angiotensin II-induced proteinuria in the rat. Am. J. Physiol. 233: F13-F21.

13. Chang, R. L. S., W. M. Deen, C. R. Robertson, and B. M. Brenner. 1975. Permselectivity of the glomerular capillary wall. III. Restricted transport of polyanions. Kidney Int. 8: $212-218$.

14. Rennke, H. G., R. S. Cotran, and M. A. Venkatachalam. 1975. Role of molecular charge in glomerular permeability. Tracer studies with cationized ferritins. J. Cell Biol. 67: $638-646$. 
15. Rennke, H. G., and M. A. Venkatachalam. 1977. Glomerular permeability: In vivo tracer studies with polyanionic and polycationic ferritins. Kidney Int. 11: 44-53.

16. Rennke, H. G., Y. Patel, and M. A. Venkatachalam. 1976. Effect of molecular charge on glomerular permeability to proteins in the rat: Clearance studies using neutral, anionic and cationic horseradish peroxidase. Clin. Res. 24: 645. (Abstr.).

17. Michael, A. F., E. Blau, and R. L. Vernier. 1970. Glomerular polyanion alteration in aminonucleoside nephrosis. Lab. Invest. 23: 649-657.

18. Blau, E. B., and A. F. Michael. 1972. Rat glomerular glycoprotein composition and metabolism in aminonucleoside nephrosis. Proc. Soc. Exp. Biol. Med. 141: 164-172.

19. Blau, E. B., and D. E. Haas. 1973. Glomerular sialic acid and proteinuria in human renal disease. Lab. Invest. 28: 477-481.

20. De Bats, A., A. H. Gordon, and E. L. Rhodes. 1974. Variation in glomerular sialic acid content in diabetes and as the result of ageing. Clin. Sci. Mol. Med. 47: 93-95.

21. Roy, L. P., R. L. Vernier, and A. F. Michael. 1972. Effect of protein-load proteinuria on glomerular polyanion. Proc. Soc. Exp. Biol. Med. 141: 870-874.

22. Caulfield, J. P., and M. G. Farquhar. 1976. Distribution of anionic sites in normal and nephrotic glomerular basement membranes. J. Cell Biol. 70: 274. (Abstr.)

23. Bennett, C. M., R. J. Glassock, R. L. S. Chang, W. M. Deen, C. R. Robertson, and B. M. Brenner. 1976. Permselectivity of the glomerular capillary wall. Studies of experimental glomerulonephritis in the rat using dextran sulfate.J. Clin. Invest. 57: 1287-1294.

24. Chang, R. L. S., W. M. Deen, C. R. Robertson, C. M. Bennett, R. J. Glassock, and B. M. Brenner. 1976. Permselectivity of the glomerular capillary wall. Studies of experimental glomerulonephritis in the rat using neutral dextran. J. Clin. Invest. 57: 1272-1286.

25. Hulme, B., and J. Hardwicke. 1968. Human glomerular permeability to macromolecules in health and disease. Clin. Sci. (Oxf.). 34: 515-529.

26. Bohrer, M. P., C. Baylis, J. L. Troy, C. R. Robertson, and
B. M. Brenner. 1977. Mechanisms of the puromycin-induced defects in the transglomerular passage of water and macromolecules. J. Clin. Invest. 60: 152-161.

27. Buerkert, J. E., J. Mor, B. N. Murray, and A. M. Robson. 1976. Glomerular permeability in disease: A proposed role of the glomerular epithelial cell. Proc. Am. Soc. Nephrol. 9: 69. (Abstr.)

28. Robson, A. M., J. Giangiacomo, R. A. Keinstra, S. T. Naqvi, and J. R. Ingelfinger. 1974. Normal glomerular permeability and its modification by minimal change nephrotic syndrome. J. Clin. Invest. 54: 1190-1199.

29. Chiu, J., and K. N. Drummond. 1972. Chemical and histochemical studies of glomerular sialoprotein in nephrotoxic nephritis in rats. Am. J. Pathol. 68: 391-406.

30. Gornall, A. G., C. J. Bardawill, and M. M. David. 1949. Determination of serum proteins by means of the Biuret reaction. J. Biol. Chem. 177: 751-766.

31. Baylis, C., W. M. Deen, B. D. Myers, and B. M. Brenner. 1976. Effects of some vasodilator drugs on transcapillary fluid exchange in renal cortex. Am. J. Physiol. 230: 11481158.

32. Deen, W. M., C. R. Robertson, and B. M. Brenner. 1972. A model of glomerular ultrafiltration in the rat. Am. J. Physiol. 223: 1178-1183.

33. Wiederhielm, C. A., J. W. Woodbury, S. Kirk, and R. F. Rushmer. 1964. Pulsatile pressures in the microcirculation of frog's mesentery. Am. J. Physiol. 207: 173-176.

34. Brenner, B. M., C. Baylis, and W. M. Deen. 1976. Transport of molecules across renal glomerular capillaries. Physiol. Rev. 56: 502-534.

35. Deen, W. M., J. L. Troy, C. R. Robertson, and B. M. Brenner. 1973. Dynamics of glomerular ultrafiltration in the rat. IV. Determination of the ultrafiltration coefficient.J. Clin. Invest. 52: 1500-1508.

36. Eisenbach, G. M., J. B. Van Liew, and J. W. Boylan. 1975. Effect of angiotensin on the filtration of protein in the rat kidney: A micropuncture study. Kidney Int. 8: 80-87.

37. Latta, H., and W. H. Johnston. 1976. The glycoprotein inner layer of glomerular capillary basement membrane as a filtration barrier. J. Ultrastruct. Res. 57: 65-67. 